\title{
REPRESENTAÇÕES IDENTITÁRIAS DA MULHER NEGRA NO BRASIL E EM MOÇAMBIQUE
}

\author{
Iza Reis Gomes Ortiz \\ Instituto Federal de Rondônia, Brasil \\ José Famir Apontes da Silva \\ Instituto Federal de Rondônia, Brasil \\ Eliane Auxiliadora Pereira \\ Instituto Federal do Acre, Brasil
}

\begin{abstract}
Resumo: O estudo presente busca expor duas representações de mulher através da Literatura. Considerando a poesia, uma forma de experiência de vida, um autoconhecer-se, evocamos Octávio Paz para dialogar com seus conceitos, pois este apresenta o espaço como um encontro do sujeito histórico com o desejo da imaginação, do sonho. E as duas poetisas que serão trabalhadas neste artigo, são sujeitos que transformam o poema em um tecido vivo, cheio de história e vida, uma história que corrompe a do dominador e apresenta outra, a dos marginalizados. Através destas reflexões sobre poesia e História, supomos que as autoras Conceição Evaristo, brasileira, e Noémia de Sousa, moçambicana, construíram uma Literatura em que a mulher é colocada em evidência, ou seja, é trabalhada, é dada a voz a ela. Duas mulheres que refletiram sobre os problemas da escravidão e do preconceito: questões de raça e de gênero. São poesias que apontam para uma realidade estampada em todos os lugares: a desigualdade de gênero. Por mais que se tenha passado por um processo de valorização da mulher, ainda há ideias de que a mulher pode dançar, cozinhar, cantar, mas escrever, nem pensar, lembrando Conceição Evaristo. Noémia constrói sua poesia como um espaço para ecoar as vozes de uma identidade que foi por muito tempo sufocada, deformada e aniquilada. Em suas poesias, ressurge a mulher negra guerreira, lutadora, cheia de cultura e vida, é redesenhado um sujeito que foi apagado pela História e pela sociedade dominante. Através de autores como Stuart Hall, Michel Foucault, Octávio Paz e Homi Bhabha, tentaremos visualizar como Conceição Evaristo e Noémia de Sousa representaram a mulher negra em suas poesias, perpassando pela História, colonização e identidade cultural.
\end{abstract}

Palavras-chave: Conceição Evaristo; Noémia de Sousa; Poesia; Mulher negra; Igualdade de gênero.

\section{Introdução}

As abordagens relativas à igualdade de gênero devem considerar todas as nuances próprias da atuação social das mulheres no mundo contemporâneo, de modo a desconstruir as imagens estigmatizantes da mulher que foram construídas no decorrer dos tempos. Antes, segundo algumas correntes histórico-descritivas, a mulher era considerada controlada, submissa, silente e resignada em relação à História que lhe era determinada pela própria história de punho masculino, contra a qual não cabiam questionamentos ou ecos da existência do universo feminino. Ao longo do tempo e em razão das implicações decorrentes de novos olhares sobre as questões de gênero, podese revisitar essa História, dando-lhe outras leituras, dentre elas o viés da construção de 
sujeito-feminino no intrincado mundo da construção histórica masculina. Parametrizados em Michel Foucault (1989), segundo o qual nossas ações são controladas, nosso discurso é polido, direcionado, é questionado se a mulher conseguiu estratégias para escapar a essa dominação, a essa aceitação ‘inquestionável'. São tratamentos de verdades que foram quebradas e reinventadas com outro olhar, revisitadas pelo olhar do sujeito-mulher, em foco a mulher negra. Nesta perspectiva, as autoras Noémia de Sousa e Conceição Evaristo nos incitam a repensar o papel da mulher na História. Esta construção será alicerçada pela análise de dois poemas, nos quais serão buscados os indícios das contribuições discursivas para o arrefecimento do preconceito contra o sujeito-mulher, sobretudo negra. Não se busca o lado frágil construído pela sociedade de sujeito-homens, mas a capacidade de um ser, reinventar sua formação identitária, utilizando-se das estratégias construídas em experiências locais e reconhecidamente subalternizadas.

A questão da subalternidade em relação à mulher foi teorizada por Spivak (2010), uma escritora indiana que ao escrever "Pode o subalterno falar?", permitiu-nos interpretar que esse subalterno pertence aos grupos em desvantagem, desfavorecidos, marginalizados. É aquele pertencente "às camadas mais baixas da sociedade constituídas pelos modos específicos de exclusão dos mercados, da representação política e legal, e da possibilidade de se tornarem membros plenos no estrato social dominante" (Spivak, 2010, p.12). Agora, imaginemos a mulher negra nesta questão, é impedida de se auto representar, por ser mulher e por ser negra. Spivak (2010) sustenta que a condição de ser mulher impõe à marginalidade, à condição da subalternidade, e sendo negra, emerge a questão racial, uma visão do racismo. Sendo assim, a mulher negra não podia falar e não possuía meios para expor suas ideias. Segundo esta autora, deviam ser criados meios para que esses grupos falem, e espaços para expor suas ideias, seus projetos, suas queixas, seus sonhos e desejos. Não apenas no mundo das reflexões, mas também nas realidades destes sujeito-mulheres negras. Nos dizeres de Spivak, a mulher negra e pobre se encaixa nos quesitos de subalternidade: pobreza, gênero e raça. Essas três condições cristalizam a mulher no lugar determinado pela sociedade: à margem do discurso oficial, nas extremidades do centro.

Já Noémia de Sousa, em uma entrevista a Michel Laban (1998), relembra uma situação que concretizava a situação do negro em geral no espaço de Moçambique: 
E eu lembro-me de uma vez estar num autocarro, num machimbombo, como se chama lá [em Moçambique] a ler um livro e um ‘senhor' troçar de mim. Foi uma coisa, eu era uma criança, devia ter para aí dez anos, que me chocou muito, tanto mais que se me dirigiu macaqueando a pronúncia do negro a falar português, com um forte sotaque a insinuar que eu não sabia ler e que estava a fingir para mostrar aos brancos. Eu era uma miúda e ele chocou-me. Está a ver? [...] Mesmo na igreja o negro tinha que ficar lá para trás, nos bancos de trás; nos autocarros, aquele banco corrido assim de trás, era para eles, não podiam vir à frente. Nós éramos descendentes de colonos, nós mestiços tínhamos direito a ficar em qualquer lugar, mas eu via os outros lá atrás. Eu via a mulher grávida negra que ficava de pé e se não fosse um dos negros a dar-lhe o lugar ninguém lhe dava; mas a senhora branca que entrava, tinha logo, fosse quem fosse, alguém que se levantasse para lhe dar o lugar, grávida ou não grávida... (Laban, 1998, pp. 268-269).

Neste depoimento, vê-se que a poetisa passou pelos problemas da discriminação racial, mais acentuadamente intensificada pela sua condição de ser mulher. Articulando com Octávio Paz (1982), a experiência da poetisa é expressa na poesia, no discurso literário, um discurso que congrega a luta do colonizado pela sua identidade.

Assim, tem-se vertentes de análise para mulher negra, tanto brasileira quanto moçambicana no enfrentamento das situações de preconceito em relação à raça e ao gênero. Neste artigo, intenta-se o desanuviamento das estratégias discursivas de luta contra estas imposições, tendo a literatura, através da poesia, como uma arma que buscaram e utilizaram contra toda sorte contextual de violência e desagravo praticados contra a mulher, resgatando o seu lugar enquanto sujeito histórico.

\section{Objetivos}

Pretende-se neste artigo investigar como as escritoras Conceição Evaristo e Noémia de Sousa representaram a mulher negra em suas poesias. O olhar dessas mulheres negras em relação à sua cultura, às suas identidades, às suas construções políticas, sociais e culturais diante de um espaço que ainda não propicia, inteiramente, abertura para os discursos das minorias, dos considerados inferiores ou 'subalternos'. Tentaremos perpassar por todas essas redes de saberes e poderes, buscando relacionar o discurso da própria mulher negra sobre si e outros discursos e grupos que falam ou trabalham com este grupo, grupo este que por muito tempo foi marginalizado, colocado às margens da sociedade.

Através de duas poesias, demonstraremos esferas da estória que se juntam à História oficial e vão ganhando força e novos contornos. Esta pesquisa tentará mostrar como 
duas poetisas fazem parte deste círculo, deste novo olhar para a História das mulheres negras.

\section{Metodologia}

Os estudos sobre as mulheres devem abarcar uma visão diferente daquela que foi durante muito tempo determinada pela História Ocidental. É uma visão que coloca a mulher como escritora, narradora e personagem da História. Restringir a Literatura escrita por mulher apenas como algo de gênero ou raça pode causar outra forma de exclusão, de preconceito. Precisa-se ver a produção feminina como outro olhar para a História, como qualquer outro pesquisador ou escritor.

E para analisar e dialogar com essas ideias, propomos nos apoderar, por um momento, das teorias do Pós-Colonialismo, da Poética da Identidade e da Análise do Discurso. O Pós-Colonialismo visa estudar como as ideias, movimentos e culturas ficaram após a colonização de um espaço. Após um período de dominação, o país passa a questionar sua posição, suas ideias, sua representação e identidade diante dos acontecimentos e do novo desenho espacial.

Trabalharemos com Edward Said e seu 'Orientalismo', considerado por alguns o início da Teoria do Pós-Colonialismo. Neste texto, Said disserta sobre a questão de construir o Outro (Oriente) através de outro olhar (Ocidente). O Orientalismo é a invenção do Oriente pelo Ocidente. Não significa que seja o 'real', mas apenas uma construção aos olhos do Ocidente. Said nos confirma isto:

O Oriente não é apenas adjacente à Europa; é também o lugar das maiores, mais ricas e mais antigas colônias europeias, a fonte de suas civilizações e línguas, seu rival cultural e uma de suas imagens mais profundas e mais recorrentes do Outro. (2007 p. 27-28). Dito isso, deve-se passar a indicar algumas observações razoáveis. Em primeiro lugar, seria errado concluir que o Oriente foi essencialmente uma ideia ou uma criação sem realidade correspondente... Havia - e há - culturas e nações cuja localização a leste, e suas vidas, histórias e costumes têm uma realidade bruta obviamente maior do que qualquer coisa que se poderia dizer a respeito no Ocidente. (Said, 2007, pp. 31-32).

Visualizando a mulher negra como a outra, a não-civilizada, a subalterna, a diferente, a não-europeia, o conceito de Oriente descrito por Edward Said dialoga com a da mulher, uma criação estereotipada sobre o mundo que não era europeu, ocidental, portanto, inferior e diferente. E os estudos de Said perpassarão pelas vozes das poetisas, vozes subalternas, emergentes e que lutam por um espaço para se expressarem, se mostrarem e mudar a visão dos outros em relação à mulher negra. 
Outro teórico que buscamos para tecer uma rede de sentidos é Stuart Hall, o qual trabalha com o conceito de identidades pós-coloniais. Após uma realidade de colonização, para qualquer grupo, a busca da identidade é essencial. Segundo Hall (2004, p. 109)

As identidades parecem invocar uma origem que residiria em um passado histórico com o qual elas continuariam a manter uma certa correspondência. Elas têm a ver, entretanto, com a questão da utilização dos recursos da história, da linguagem e da cultura para a produção não daquilo que nós somos, mas daquilo no qual nos tornamos. Têm a ver não tanto com as questões "quem nós somos" ou "de onde nós viemos", mas muito mais com as questões "quem nós podemos nos tornar", "como nós temos sido representados" e "como essa representação afeta a forma como nós podemos representar a nós próprios”

A questão central é verificar se as duas poetisas em seus distintos espaços de atuação podem vir a contribuir para a desconstrução do preconceito que ainda hoje as mulheres negras sofrem, seja em Moçambique ou Brasil.

A poética da Identidade será pautada nas reflexões de Octávio Paz (1982), em seu texto 'A lira e o arco', que aborda questões de criação entre poesia e identidade, entre o eu lírico e a experiência do sujeito. Segundo Paz, a criação poética é

Exercício de nossa liberdade, de nossa decisão de ser. Essa liberdade, conforme já foi dito muitas vezes, é o ato pelo qual vamos mais além de nós mesmos, para sermos mais plenamente. Liberdade e transcendência são expressões, movimentos da temporalidade. A inspiração, a 'outra voz', a 'outridade' são, na sua essência, a temporalidade brotando, manifestando-se sem cessar. Inspiração, 'outridade', liberdade e temporalidade são transcendência (Paz, 1982, p. 218).

Com este conceito, tentaremos nos indagar sobre a posição criativa das poetisas em relação à experiência de vida, como sujeitos que participam e se identificam com a realidade política, cultural, econômica e social de uma determinada sociedade.

A Análise do Discurso virá com o filósofo Michel Foucault, ao trabalhar a questão do discurso e do poder, para o filósofo, o conhecimento é adquirido através do discurso, ou seja, precisamos nos expressar para sermos ouvidos e declarar nossas posições sujeitos em relação à realidade. Outro conceito a ser trabalhado com Foucault são as 'vontades de verdade', ou seja, a quebra de paradigmas determinados por um grupo que detém o poder naquele momento. Esses totens podem ser questionados, discutidos, reavaliados e reescritos conforme o novo discurso do sujeito. A novidade não está no que é dito, mas no como esse dito voltou, ou seja, quais estratégias e subjetivações o sujeito 
'mulher negra' construiu para representar a si mesmo e apresentar ao mundo sua visão da História do mundo.

\section{Conceição Evaristo não canta, nem dança, ESCREVE.}

Em uma entrevista ${ }^{1}$ de Conceição Evaristo cedida à Revista Raça Brasil (2007), perguntada sobre a questão do papel da mulher na sociedade, comentou:

Espera-se que a mulher negra seja capaz de desempenhar determinadas funções, como cozinhar muito bem, dançar, cantar, mas não escrever. Às vezes me perguntam: 'você canta?'. E eu digo: 'não canto nem danço.

Com este comentário não quer criar nenhum mal-estar com as mulheres que cantam ou dançam, mas apenas mostrar que a mulher negra não apenas canta, dança, cozinha, mas também escreve, constrói discursos sobre a raça e o gênero, tentando mostrar que a educação, os questionamentos, as perguntas sobre determinadas posições e verdades prontas, pode criar conhecimento, pode mudar o foco do olhar, o ângulo da História.

A escritora Conceição Evaristo é considerada o pilar e a mais importante e atuante voz da Literatura Afro-brasileira, atualmente. Sua origem é Minas Gerais, cresceu na favela, conheceu a pobreza de perto. Pertencia a uma família de cozinheiras, queria outro futuro para si, desejava estudar, mas como? Sua mãe, uma lavadeira. Uma importante peça na sua construção de leitura, aquela contava histórias para os filhos, exercia o papel de contadora de histórias. Com muita dificuldade, terminou os estudos básicos, optou por Letras por ter sido incentivada à leitura, quando criança, por sua mãe, a contadora de histórias oficial. Fez Mestrado em Literatura Brasileira pela PUC do Rio de Janeiro, defendendo em 1996 a dissertação: Literatura Negra: uma poética da nossa afro-brasilidade, e doutorou-se em Literatura Comparada pela Universidade Federal Fluminense. Sua tese versou sobre a Literatura Brasileira afrodescendente e as Literaturas de Língua Portuguesa.

Esta poetisa negra busca apresentar ao público leitor uma História diferente da oficial, divulgada pelos representantes do poder. Conceição é uma representante da mulher negra crítica, revolucionária, questionadora. A sua escrita é perpassada por suas experiências, pelo seu viver. Em suas palavras, percebemos a importância da escrita na sua vida, como passou a ser uma forma de luta contra os paradigmas da escravidão e do servilismo das mulheres negras:

\footnotetext{
${ }^{1}$ Entrevista com Conceição Evaristo. Enpublicacion: Boletín PPCOR, no. 31. LPP, Laboratório de Políticas Públicas, UERJ: Brasil. Abril-Maio. 2007. Aceso ao texto completo: http://www.lppuerj.net/olped/acoesafirmativas/boletim/31/entrevista.htm
} 
e se inconscientemente desde pequena nas redações escolares eu inventava um outro mundo, pois dentro dos meus limites de compreensão, eu já havia entendido a precariedade da vida que nos era oferecida, aos poucos fui ganhando alguma consciência. Consciência que compromete a minha escrita como um lugar de autoafirmação de minhas particularidades, de minhas especificidades como sujeitomulher-negra. (Evaristo, 2007, p. 20)

A poetisa consegue construir em sua poesia um lugar para a voz da mulher negra, através da poesia, contornar o discurso oficial e subverter a ordem do mesmo. Evocando Foucault, seria uma estratégia de subjetivação, uma forma de escapar aos mandos e desmandos da sociedade que teima em dizer e assegurar a submissão de determinados sujeitos, colocá-los como inferiores. E Evaristo refaz a História, assegurando um espaço para as ideias, os desejos, os lamentos, para a História da mulher negra. A escolha pela poesia EU-MULHER, deu-se pela presença do eu-lírico se questionar e se identificar com a construção de efeitos de sentido do vocábulo "mulher".

Vamos analisar todo este caminhar na seguinte poesia:

\section{EU-MULHER}

Uma gota de leite me escorre entre os seios. Uma mancha de sangue me enfeita entre as pernas Meia palavra mordida me foge da boca. Vagos desejos insinuam esperanças.

$\begin{array}{ll}\begin{array}{l}\text { Eu-mulher em rios } \\ \text { vermelhos }\end{array} & \begin{array}{l}\text { Eu fêmea-matriz. } \\ \text { Eu força-motriz. }\end{array} \\ \begin{array}{l}\text { inauguro a vida. } \\ \text { Em baixa voz } \\ \text { violento os tímpanos do } \\ \text { mundo. }\end{array} & \begin{array}{l}\text { Eu-mulher } \\ \text { abrigo da semente } \\ \text { moto-contínuo } \\ \text { do mundo. }\end{array} \\ \begin{array}{l}\text { Antevejo. } \\ \text { Antecipo. }\end{array} & \text { (Evaristo 1990: 32) } \\ \begin{array}{l}\text { Antes agora o que há de } \\ \text { vir. }\end{array} & \end{array}$

A poetisa consegue construir todo um conjunto entre passado, presente e futuro através da memória. Podemos considerar a escrita da poesia uma forma de resistência, uma estratégia de luta para não concordar com a posição de subalternidade. Escrever é uma forma de mostrar sua identidade através de sua própria voz:

O que eu tenho pontuado é isso: é o direito da escrita e da leitura que o povo pede, que o povo demanda. É um direito de qualquer um, escrevendo ou não segundo as normas cultas da língua. É um direito que as pessoas também querem exercer. Então Carolina Maria de Jesus não tinha nenhuma dificuldade de dizer, de se afirmar como escritora. (...) E quando mulheres do povo como Carolina, como minha mãe, como eu, nos dispomos a escrever, eu acho que a gente está rompendo com o lugar que normalmente nos é reservado, né? A mulher negra, ela pode cantar, ela pode dançar, ela pode cozinhar, ela pode se prostituir, mas 
escrever, não, escrever é uma coisa... é um exercício que a elite julga que só ela tem esse direito. (...) Então eu gosto de dizer isso: escrever, o exercício da escrita, é um direito que todo mundo tem. Como o exercício da leitura, como o exercício do prazer, como ter uma casa, como ter a comida (...). A literatura feita pelas pessoas do povo, ela rompe com o lugar pré-determinado. ${ }^{2}$

Desta forma, a poetisa se coloca na poesia e em seus textos na mesma posição que seus personagens e seus antecessores, no caso, sua avó. São sujeitos inseridos em uma rede de representações que buscam validar o discurso do Outro, do colonizado, do subjugado.

Estudar os marginais, as laterais do poder, implica dar voz aos excluídos, automaticamente, discutir os paradigmas, as verdades estabelecidas, a ordem do discurso dominante. Não há outra forma de colocar este assunto em voga, senão através do próprio discurso do dominado, do considerado incapaz. É uma tentativa de produzir sujeitos, individual ou coletivamente, capazes de auto representar sua cultura, suas cores, suas bandeiras de luta. E a poesia é um meio que Evaristo encontrou para disseminar e discutir esses paradigmas, esses conceitos, essas 'verdades'. Mas como disse Foucault, não temos 'verdades', temos 'vontades de verdade', ou seja, dependendo de quem fala, para quem fala, quando fala, como fala, teremos interesses e construções diferentes.

Em sua poesia 'Eu mulher', Conceição Evaristo nos apresenta várias definições de mulher, várias características ímpares que a mulher, de forma geral, possui em sua constituição. No título, já há uma autoafirmação, uma auto definição: 'Eu-Mulher'. Não se sabe se o eu-lírico está dentro da poetisa ou a poetisa está dentro do eu-lírico 'mulher'. Assim como a escritora, o eu-lírico busca afirmar um espaço, uma identidade feminina maiúscula, forte e segura de sua construção. No primeiro verso, temos o índice da mãe, 'Uma gota de leite me escorre entre os seios', uma imagem que gera o sentido de criação, de produzir alimento, de dar vida a outro ser. Mas também evoca a imagem de tristeza, comparando a gota de leite à gota de lágrima, a um corpo que chora pelos maus tratos ocasionados pelo patrão. O verso 'uma mancha de sangue me enfeita a perna' sinaliza o parto, o nascimento do filho, a geradora da vida, o ser que dá a vida aos outros. A questão do dizer, do falar, do se identificar é cortada, é interrompida: 'meia palavra mordida me foge a boca'. Tenta dizer algo, mas algo ou alguém a impede, a interrompe. O ser mulher no momento de sua função mais magistral, dar a

\footnotetext{
${ }^{2}$ Entrevista de Conceição Evaristo concedida a Bárbara Araújo (Blogueiras Feministas) em 30 de setembro de 2010. Disponível em http://racabrasil.uol.com.br/Edicoes/96/artig015620-2.asp/ Acesso em 25 de abril de 2012.
} 
vida a outro ser, é inibida, é tolhida, por ela mesma, demonstrando medo, ou por força de outro sujeito considerado superior. No decorrer da poesia, há o desejo da vida ser diferente, da esperança em um novo ser: 'Vagos desejos insinuam esperanças / Eumulher em rios vermelhos inauguro a vida.' Ao mesmo tempo que demonstra medo, fragilidade com as palavras 'vagos' e 'insinuam', ou seja, desejos imprecisos, parecem que não podem ser desejados, não estão claros, e 'insinuam' remete-se a não afirmar, a não se declarar; também demonstra uma veemência na hora que se diz mulher inaugurando a vida em rios vermelhos, este sangue que pode ter dois efeitos de sentido: o do sangue da nova vida, do ato de nascer, e também ser mulher na guerra, na luta, na morte. E quando o eu-lírico expressa o sentimento através da hipérbole 'em rios vermelhos', nos remete ao coletivo, a mais de uma mulher, a várias mulheres dando vida a outros, através da luta de sangue ou através da luta do nascer. Nascer mulher e ainda negra, pode determinar o futuro daquela criança, dependendo do momento histórico em que nasceu. No decorrer da poesia, temos uma reviravolta, o ser mulher assume seu papel de construtora de ideias, de espaços, de revolta e de mudança. Quando diz 'em baixa voz violento os tímpanos do mundo', nos diz que aos poucos, devagar a mulher está conseguindo se identificar, se mostrar, não impondo, mas de modo não repressivo ou manipulador, de forma questionadora e reflexiva. É a vez de ouvir a voz da mulher, do sujeito que foi destinado pela sociedade a manter-se na alcova, na cozinha, nos bastidores, à margem da História. A partir do verbo 'inaugurar', o eu-lírico parte para a ação, coloca-se como sujeito ativo da História, não serão mais 'vagos desejos' ou 'insinuações', agora são afirmações, verbos de ação: “eu inauguro a vida / Antevejo. / Antecipo.” Há uma demonstração da força da mulher, agora ela vê e fala, possui o poder de se expressar, possui o poder do discurso, possui assim, o poder do conhecimento. Era uma mulher que vivia no passado, espaço este criado pelos dominadores, pelos que disseram que a mulher não era igual ao homem, era inferior, frágil e incapaz. Em seguida, o eu-lírico utiliza o advérbio 'agora' para determinar uma mudança no tempo, tudo era antes, 'agora - o que há de vir' - evoca a representação da mulher da sociedade, a luta das mulheres contra a desigualdade em todos os sentidos, não importa o 'antes', 'o agora' ou 'o que há de vir', tudo será enfrentado pela mulher, por ela, a força motriz e matriz da geração do mundo. É uma forma de gritar ao mundo, 'estou aqui e agora em diante, vocês irão me ouvir'. Nos últimos versos, há auto-adjetivação, um nomear-se como 'força matriz' e propulsora dos novos tempos que virão: "Eu fêmea-matriz." Neste verso, temos a marcação da identidade de gênero, a mulher que gera, que é a origem.

Ela reclama um lugar para ecoar o discurso de outras vozes, precisa-se descortinar o véu que cobre a História dos marginalizados, das culturas não estudadas, das Histórias 
não escritas. Desta forma, a sociedade sempre direcionou o seu discurso em relação ao negro como algo a ser controlado, selecionado, pois se vendia a ideia de que negro não tinha alma, negro só servia para trabalho escravo, considerado inferior cientificamente, através de estudos em relação ao tamanho do cérebro, pesagem. Assim, criava-se uma imagem do negro e defendia-se como verdade, como algo a ser temido. A cultura islamita justificava a escravidão no século XVI com as seguintes ideias em relação aos negros: "são brutos sem razão, sem inteligência e sem experiência. Eles não têm absolutamente nenhuma noção do que quer que seja. Eles assim vivem como as bestas, sem regra e sem leis" (Cohen apud Santos, 2006).

Temos então a luta do negro (mulher ou homem) por sua representação, por sua identidade, pela sua auto representação. $\mathrm{E}$ os três últimos versos nos mostram a vontade de verdade da mulher em se emancipar e se construir como sujeito ativo e participativo da sociedade do mundo: "Eu-mulher / abrigo da semente / motocontínuo do mundo.” Em outras palavras, o eu-lírico apresenta-se mulher, geradora da vida e mola propulsora da continuidade da vida, do mundo. Diferente do início do poema, o eu-lírico consegue visualizar seu papel e função diante de todos, reclamando um espaço e um ouvir para os outros a olharem diferente da visão que foi construída pelos colonizadores e exploradores existentes. Façamos um diálogo desta realidade com os dizeres de Conceição sobre o exercício de ser escritora em uma entrevista à Revista Raça ${ }^{3}$ :

Para um negro desconhecido tornar-se escritor, há todas essas dificuldades. Para uma mulher negra, pode multiplicar isso por mil, pois você vai assumir uma função que a sociedade não está acostumada a esperar. A sociedade tem uma expectativa que nunca é intelectual.

Ou seja, confirma-se a ideia de que precisamos rever os discursos em relação ao negro, e especificamente, à mulher negra. Conceição Evaristo é uma escritora que luta por isso, tenta mostrar sua visão ao mundo, de seu lugar e posição como mulher negra e escritora.

\section{Noémia de Sousa, uma filha da Mãe-África}

Agora, partiremos para Noémia de Sousa, uma escritora moçambicana que também representa a mulher negra em sua poesia. Antes, façamos uma ponte entre as duas poetisas. Em uma entrevista, Conceição Evaristo falou sobre a importância da Literatura Africana de Língua Portuguesa:

\footnotetext{
${ }^{3}$ Entrevista de Conceição Evaristo cedida à Revista Raça Brasil. Disponível em < http://racabrasil.uol.com.br/Edicoes/96/artig015620-2.asp > Acesso em 30.08.2012.
} 
Qual a importância da Literatura Africana na Língua Portuguesa e na Literatura Brasileira?

- Creio que essa pergunta coloca dois níveis de questões distintas. Eu diria que a importância das Literaturas Africanas na Língua Portuguesa estaria na possibilidade de ampliação de sentidos da própria língua portuguesa. Os escritores africanos que herdaram da colonização portuguesa, como nós herdamos, o idioma português, fazem "maravilhas", produzem novos efeitos estéticos com uma língua que, desde que emigrou da metrópole para as suas antigas colônias, deixou de ser só a língua de Camões. Transformou-se em uma língua que ganhou novos donos, novas marcas culturais, diversificou-se, enriqueceu-se ao misturar-se com locais falares, por onde ela aportava. Falamos, todos nós, uma mesma língua. Falamos e não falamos... E do ponto de vista da linguagem, nesse falar e não falar a mesma língua portuguesa reside, muitas vezes, o fundamento estético dos textos africanos. A segunda pergunta, talvez seja preciso inverter. Seria qual a importância da literatura brasileira nas literaturas africanas? Interessante observar que os escritores brasileiros, notadamente os modernistas, tiveram uma grande influência nas literaturas africanas de língua portuguesa. Jorge Amado, Guimarães Rosa, o poeta Manuel Bandeira e outros marcaram a escrita de escritores africanos. Há vários textos africanos que dialogam com uma escrita brasileira. Só para exemplificar, podemos pensar na escrita do angolano Luandino Vieira e do moçambicano Mia Couto. ${ }^{4}$

Com estes dizeres, percebemos que Conceição possui consciência de sua ligação com a Literatura Africana de Língua Portuguesa. São expressões de representação que evocam uma História silenciada que precisa ser contada e escrita, para também fazer parte da História oficial, ou possuir o mesmo status para ser repassada a todos os leitores.

Noémia de Sousa, uma escritora moçambicana que lutou pela África, pelo povo africano, representou todas as possíveis dores do povo colonizado, sua escrita é agressiva, reclamadora, exaltante. Nasceu em Catembe, Moçambique, em 1926, escreveu vários poemas, reunidos em "Sangue Negro". Morreu, aos 82 anos em 2003, em Cascais, Portugal. Sua poesia pode ser considerada agressiva, mas ela consegue chamar atenção através desta estratégia, de chocar o leitor com imagens sobre a África. Francisco Noa comentou sobre a escrita de Noémia:

\footnotetext{
${ }^{4}$ Entrevista com Conceição Evaristo. En publicacion: Boletín PPCOR, no. 31. LPP, Laboratorio de Políticas Públicas, UERJ: Brasil. Abril-Maio. 2007. Acceso ao texto completo: http://www.lppuerj.net/olped/acoesafirmativas/boletim/31/entrevista.htm
} 
O pendor apelativo e messiânico que caracteriza o seu verso, a exaltação dos valores negro-africanos, o afrontamento corrosivo às imagens do europeu acerca dos africanos, a (re)constituição da sua própria imagem identitária são algumas das marcas mais evidentes do alinhamento estético da escrita da Noémia por uma reivindicação sobretudo com um profundo sentido humanista. (Noa, 2001, pp. 157158)

Assim, Noa nos afirma que a escrita de Noémia é uma tentativa de reclamar um espaço e um momento para mostrar a identidade da África, ao mesmo tempo, a identidade do povo africano e da mulher africana. É um espaço em que Colonialismo e Anticolonialismo são representados por um sujeito que representa o povo colonizado, o subalterno, que não tinha direito a nada, apenas a obedecer ao colonizador. Frantz Fanon (2005) no livro "Os condenados da terra", nos apresenta a ideia do colonizador em relação ao continente africano: "Para o colonialismo, esse vasto continente era um antro de selvagens, uma região infestada de superstições e fanatismo, digna de desprezo, carregada de maldições divinas, lugar de antropófagos, lugar de negros" (Fanon, 2005, p. 245). Contra esta ideia Noémia lutava, imagens como estas figuravam em suas poesias para que todos soubessem o verdadeiro olhar da Europa para com os africanos.

Refletindo sobre esse discurso do colonizador, Noémia de Sousa tenta abrir os olhos dos leitores enaltecendo a Mãe África. A escolha pela poesia "Sangue negro" deu-se visando a relação do eu-lírico com o espaço África e a identidade da mulher com a História. Vamos à leitura da poesia. 
SANGUE NEGRO

Ó minha África

misteriosa, natural!

Minha virgem violentada!

Minha Mãe!...

Como eu andava há tanto

desterrada

de ti, alheada distante e

egocêntrica

por estas ruas da cidade

engravidadas de

estrangeiros

Minha Mãe! Perdoa!

Como se eu pudesse viver assim,

desta maneira,

eternamente,

ignorando a carícia,

fraternalmente morna

do teu olhar... Meu

princípio e meu fim...

Como se não existisse para além dos cinemas e cafés a ansiedade dos teus horizontes estranhos, por desvendar...

Como se nos teus matos cacimbados,

não cantassem em surdina

a sua liberdade, as aves mais belas,cujos nomes

são mistérios ainda

fechados!

Como se teus filhos

- régias estátuas sem par -

altivos, em bronze

talhados,

endurecidos no lume

infernal

do teu sol

causticante

tropical -

Como se teus filhos

intemeratos, sofrendo,

lutando,

à terra amarrados

como escravos

trabalhando, amando,

cantando,

meus irmãos não fossem!

- Ó minha mãe África -

Magna pagã, escrava

sensual

mística, sortílega,

à tua filha tresvairada,

Abre-te e perdoa!

Que a força da tua seiva

vence tudo

e nada mais foi preciso

que o feitiço impor

dos teus tantãs de guerra

chamando, dum-dum-dum-tam-tam-

tam

dum-dum-dum-tam-tam-

tam

para que eu vibrasse

para que eu gritasse

para que eu sentisse!

- fundo no sangue a tua

voz - Mãe!

$\mathrm{E}$ vencida reconhecesse os

nossos erros

e regressasse à minha

origem milenar...

Mãe! Minha mãe África, das canções escravas ao

luar,

Não posso, NÃO POSSO,

renegar

o Sangue negro, o sangue

bárbaro

que me legaste...

Porque em mim, em

minha alma, em meus

nervos, ele é mais forte que tudo!

Eu vivo, eu sofro, eu rio, através dele.

Mãe!

(Sousa, 1988, pp. 25-26)

Sua poesia parece sangrar, mostrar as feridas ao mundo, o sofrimento que o colonizador causou ao território África e metaforicamente aos sujeitos africanos. O título já traz uma carga semântica bem enfática: "Sangue negro", o sangue não é vermelho, é negro, relacionando à raça, ao negro da África. Os primeiros versos já apresentam a intenção de denúncia do eu-lírico: “Ó minha África misteriosa, natural! / Minha virgem violentada! / Minha Mãe!...”, há no início uma evocação da África junto com o sentimento de pertencimento e da exaltação do natural, ou seja, ainda intacta, sem a presença do invasor, repleta de mistérios, superstições, mandingas, rituais; mas no próximo verso temos a violência, a invasão do colonizador que sem piedade, invadiu e determinou sua raça como mais poderosa, mais bonita e mais correta. Aniquilou a cultura do outro e impôs a sua cultura eurocêntrica. E por fim, compara a África à sua mãe, a tantas mães que foram também violentadas, amedrontadas, silenciadas pela força do homem branco. 
Os versos seguintes apresentam o remorso, a vontade de regressar ao espaço da mãe, da África mãe: “Como eu andava há tanto desterrada / de ti, alheada distante e egocêntrica / por estas ruas da cidade engravidadas de estrangeiros / Minha Mãe! Perdoa!” Nestes versos, temos o eu-lírico feminino desgarrado, perdido, distante da mãe que deu origem, que trouxe ao mundo, das raízes étnicas e raciais. O eu-lírico apresenta a situação da mãe-África com ruas da cidade engravidadas de estrangeiros: o colonizador invadiu e deixou frutos na terra invadida, são sujeitos que não possuem a cultura da África, não praticam as danças, os rituais, são estrangeiros literalmente. E o eu-lírico pede perdão para retornar à mãe (espaço África), aos costumes, à cultura africana, às origens.

No decorrer da poesia, há um re-olhar para a África, para sua valorização. Noémia expõe toda uma angústia ao ter ficado distante de seu espaço, de suas raízes. Colocanos a importância da mãe-África na vida dela.

Noémia de Sousa apresenta-nos uma África cheia de beleza, de espaços a serem desvendados, mas de forma humanística, não violenta. A liberdade está sempre presente, sempre evocada, na surdina, na beleza das aves mais belas ou nos nomes misteriosos que abarcam toda uma configuração cultural.

Há uma nomeação dos filhos da África, os escravos que trabalham, mas ao mesmo tempo, cantam e amam o lugar de sua terra, de suas origens. E o eu-lírico se pergunta, como renegar toda essa História, toda essa cultura, os irmãos africanos que ficaram e enfrentaram a colonização, sofrendo e lutando, debaixo do sol causticante? O Eu-lírico pede perdão, licença para retornar ao seio materno.

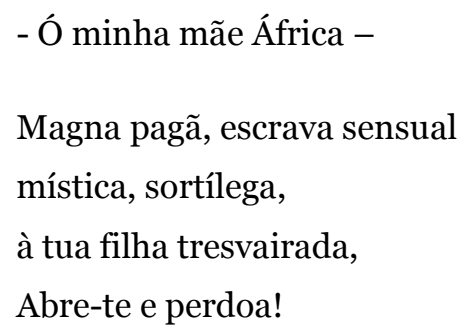

E como se fosse uma filha pedindo perdão à mãe, pedindo ajuda, perdão por ter ficado um longo tempo distante, implora os braços abertos e o perdão à filha "tresvairada". Há o reconhecimento do valor da África, lugar que foi colonizado, mas também apresenta resistência através dos seus tambores, dos instrumentos de luta construindo o som da guerra, da evocação dos filhos: 


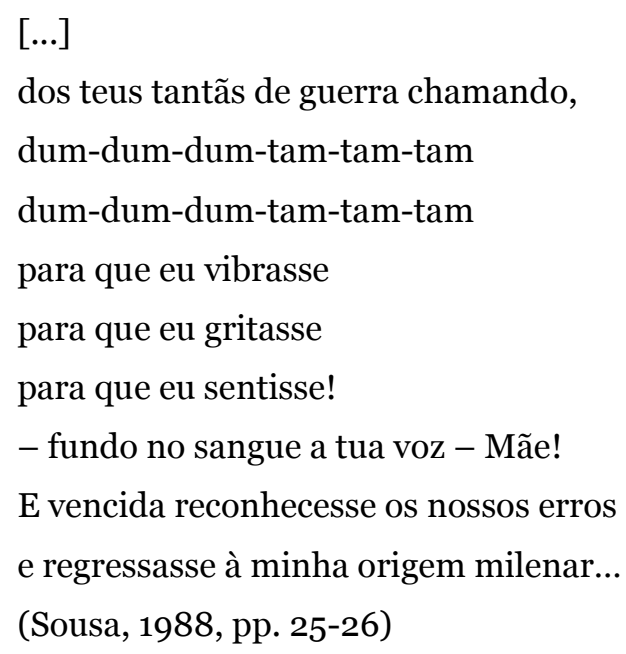

O som dos tantãs causou efeitos de sentido em seu viver, o eu-lírico vibrou, gritou e sentiu a presença da voz da mãe-África, chamando, conclamando sua presença na Terra colonizada. E vencida pela força da mãe-África, regressa à sua origem, ao seu espaço de pertencimento.

E por fim, o eu-lírico se convence do poder que a África possui em evocar seus filhos, seus representantes, em lutar contra o colonialismo do lugar de origem. O eu-lírico só é representável através de seu espaço, de seu lugar, de sua cultura, de seu sofrimento, de sua busca pela liberdade. Ele vive, sofre, se alegra através de seu contexto social e histórico. É a identidade de raiz, raça, gênero, de se representar mulher negra através de sua luta, junto com os outros irmãos negros que sofreram junto a ela, não iguais, mas ao lado. São posições sujeitos que estão sendo reavaliadas, resignificadas diante do discurso, da voz ecoando e ressonando pelo mundo. A presença do estrangeiro, do outro provoca uma mudança na conjuntura cultural da África, ameaçando a identidade africana, os rituais, as posições ocupadas pelos homens e mulheres negras. Noémia de Sousa nos apresenta uma África sangrando, mas também uma África orgulhosa de sua negritude.

\section{Algumas conclusões}

Na poética da desconstrução de discursos, Conceição Evaristo e Noémia de Sousa ensaiam a busca do entre-lugar, um espaço de reflexão sobre a verdade do colonizador e o desejo de invenção de uma nova verdade libertadora à luz do contexto do sujeitomulher colonizado, articulado por processos culturais que enfatizam as diferenças, que dão possibilidades de novas identidades, individuais e/ou coletivas, de onde derivaria uma subjetivação genuína, transformadora, re-afirmadora ou contestadora da realidade, mas que instigasse a mudança, construísse um olhar feminino ao sujeito colonizado, subalterno e considerado, por alguns como inferior (Bhabha, 2005). 
A recuperação da ancestralidade nas duas autoras nos mostra a dimensão histórica e política no viés da Literatura. A poesia transformada em arma, em luta de dizeres, de desconstrução discursiva que reconstrói a realidade, outro fio da História. A poesia é um espelho da identidade dessas mulheres, representa a entrega à imaginação e ao saber refazer o conhecimento, rediscutir as verdades prontas e acabadas.

Por outro viés, as poesias possuem uma força cultural enorme, à medida que estabelece uma relação pujante com a oralidade, com o falar do povo, com o cotidiano. Estas possíveis leituras de resistências oriundas de Conceição Evaristo e Noémia de Sousa catalisam diferentes visões que se reportam às pessoas e suas impressões sobre as mulheres negras. As autoras, por esta leitura, almejam a construção de um sujeito social feminino capaz de dar voz às experiências vividas e/ou rememoradas. Nesta vertente, as autoras desaviltam o ver literário como um conjunto entre interior e exterior e ampliam este ver às representações femininas imersas num contexto social, comprometidas com as "verdades" insculpidas nas questões políticas, sociais e históricas, inclusive de submissão e posicionamentos de resistências. Os discursos das poetisas podem rasurar a História Oficial, marginalizá-la, infiltrá-la em discursos nãooficiais para que possam ser visualizados e estudados também como silenciamentos estratégicos, propositadamente acionado contra o domínio e o poder patriarcal e colonial.

O sujeito-mulher presente nas poesias das duas autoras incorpora-se de posições marginais e centrais, ocasionando um deslocamento do pensamento social sobre a mulher negra. Numa possibilidade de tornar este sujeito crível, presente e visível com todas as armas poéticas que uma mulher pode conquistar e construir para que sua presença não seja vista apenas como coadjuvância da suprarrealidade, mas também como tudo que lhe é permitido por autoria declarada.

\section{Referências bibliográficas}

Araújo, B. (2010, 30 de setembro). Entrevista concedida por Conceição Evaristo a Bárbara Araújo. (Blogueiras Feministas).

Bhabha, H. K. (2005). O Local da Cultura. (M. Ávila, E. L. de L. Reis \& G. R. Gonçalves, Trad.). Belo Horizonte: Ed. UFMG.

Evaristo, C. (1990). Cadernos Negros 13. São Paulo: Quilombhoje.

Evaristo, C. (2007). Entrevista com Conceição Evaristo. Enpublicacion: Boletín PPCOR, no. 31. LPP, Laboratório de Políticas Públicas, UERJ: Brasil. Abril-Maio. 2007. Acesso ao texto completo: http://www.lpuerj.net/olped/acoesafirmativas/boletim/31/entrevista.htm 
Fanon, F. (2005). Os Condenados da Terra. (E. A. Rocha, L. Magalhães, Trad.). Juiz de Fora: Ed. UFJF.

Foucault, M. (1989). Microfísica do poder. (R. Machado, Trad.). 8 ed. Rio de Janeiro: Graal.

Frederico, C. (2012). Entrevista de Conceição Evaristo cedida à Revista Raça Brasil. Disponível em < http://racabrasil.uol.com.br/Edicoes/96/artigo15620-2.asp > Acesso em 30.08.2012.

Hall, S. (2004). A identidade cultural na pós-modernidade. Rio de Janeiro: DP\&A.

Laban, M. (1998). Moçambique. Encontro com Escritores. (Vol 1). Porto: Fundação Eng. António de Almeida.

Noa, F. (2001). Noémia de Sousa: a metafísica do grito. In: SOUSA, Noémia de. Sangue Negro. Maputo.

Paz, O. (1982). O arco e a lira. (O. Savary, Trad.). Rio de Janeiro: Nova Fronteira.

Said, E. W. (2007). Orientalismo: o Oriente como invenção do Ocidente. São Paulo: Companhia das Letras.

Santos, G. A. dos. (2006). A Invenção do Ser Negro: um percurso das ideias que naturalizaram a inferioridade dos negros. São Paulo: Educ/Fapesp; Rio de Janeiro: Pallas.

Sousa, N. de. (1988). Sangue Negro. Moçambique: Associação de Escritores Moçambicanos.

Spivak, G. C. (2010). Pode o subalterno falar? Minas Gerais: UFMG.

Iza Reis Gomes Ortiz é doutoranda em Sociedade e Cultura na Amazônia pela UFAM; Mestre em Letras: Linguagem e Identidade pela UFAC; Professora do Instituto Federal de Rondônia (IFRO); Coordenadora do NEABI - Núcleo de Estudos Afro-brasileiros e Indígenas do IFRO; Pesquisadora no Grupo Poesia Africana do Séc. XX e XXI da UFRJ. iza.reis@ifro.edu.br

José Famir Apontes da Silva é Mestre em Linguística pela UNIR; Professor do Instituto Federal de Rondônia (IFRO); Coordenador do NEABI.

jose.famir@ifro.edu.br

Eliane Auxiliadora Pereira é Doutoranda em Sociedade e Cultura na Amazônia pela UFAM; Mestre em Literatura e Crítica Literária pela PUC de Goiás; Professora do Instituto Federal do Acre (IFAC); Membro do NEABI do IFRO.

eliane.pereira@ifac.edu.br 